\title{
LATE CAMBRIAN BRACHIOPODS FROM THE DENISON RANGE, SOUTHWESTERN TASMANIA
}

\author{
by J. B. Jago
}

(with one text-figure and two plates)

JAGO, J.B., 1989 (31:x): Late Cambrian brachiopods from the Denisøn Range, southwestern Tasmania. Pap. Proc: R. Soc. Tasm. 123: 37-42. https://doi.org/10.26749/rstpp.123.37 ISSN 0080-4703. Department of Applied Geology, South Australian Institute of Technoløgy, The Levels Campus, S•uth Australia 5095.

Eight unnamed species of brachiopods and one indeterminate hyolithid species are described and figured from three stratigraphic intervals within the early Late Cambrian Singing Creek F•rmation, Denison Range, southwestern Tasmania.

Key Words: brachiopod, hyolithid, Cambrian, Tasmania.

\section{INTRODUCTION}

The purpose of this paper is to document the brachiopods and hyolithids from the Singing Creek Formation of the Denison Range in southwestern Tasmania. The Middle Cambrian to Lower Ordovician stratigraphy of the Denison Range area (Corbett 1975) may be summarised as follows:

\section{Denison Group -}

\begin{tabular}{lr} 
Squirrel Creek Formation & $600 \mathrm{~m}$ \\
Reeds Conglomerate & $1560 \mathrm{~m}$ \\
Great Dome Sandstone & $510 \mathrm{~m}$ \\
Singing Creek Formation & $720 \mathrm{~m}$ \\
\cline { 2 - 2 } Trial Ridge Beds & $500 \mathrm{~m}$
\end{tabular}

The upper part of the Trial Ridge Beds contains fossils of the late Middle Cambrian Lejopyge laevigata Zone (Jago 1979). The Great Dome Sandstone is a shallow marine-deltaic-fluvial sequence which contains abundant trace fossils, rare inarticulate brachiopods, and a gastropod similar to Kobayashiella (Corbett 1975).

The Singing Creek Formation comprises $720 \mathrm{~m}$ of quartzwacke turbidites interbedded with fossiliferous siltstone, siliceous conglomerate and slump sheets, deposited as a submarine fan complex in a fault-controlled basin (Corbett 1972, 1973, 1975). In the Denison Range, fossils are found over three stratigraphic intervals (fig. 1). Jago (1987) described the trilobites; the brachiopods and hyolithids are described herein.

The specimens were collected by K.D. Corbett in 1967 and 1968 as bulk samples rather than on a bed-by-bed basis, because of the nature of the

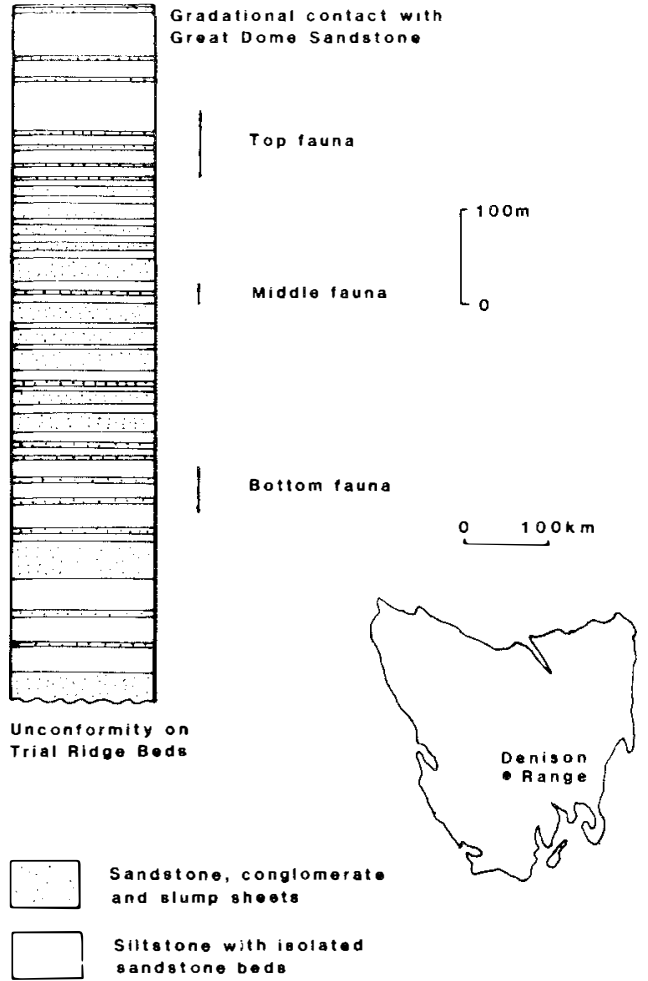

FIG. 1 - Stratigraphic position of the faunas from the Singing Creek Formation, Denison Range, southwestern Tasmania. Rock types after Corbett (1975: fig. 2). The location of Denison Range is shown. 
outcrop and the difficulties of collection in this rather inaccessible area.

The lowest fauna, occurring between about 185 and $240 \mathrm{~m}$ above the base of the Singing Creek Formation, contains the following:

Trilobita (see Jago 1987): Micragnostus, Pseudanostus idalis denisonensis, Denagnostus corbetti, Eugonocare, Dokimocephalidae and Proceratopyge.

Brachiopoda: Lingulella (?) sp., Acrotretidae, gen. et sp. indet. 1, and Billingsella sp. 1.

Only Pseudagnostus idalis denisonensis and Billingsella sp. 1 are reasonably abundant.

The middle fauna, occurring between about 410 and $430 \mathrm{~m}$ above the base of the Singing Creek Formation, contains the following:

Trilobita: Denagnostus corbetti, Aphelaspis cantori, Proceratopyge gordonensis, P. sp., Pseudoyuepingia vanensis and trilobite tracks.

Hyolithida: Hyolithid, gen. et sp. indet.

Brachiopoda: Lingulella (?) sp., and Obolus (?) sp. In this fauna Proceratopyge gordonensis, $P$. sp. and Pseudoyuepingia vanensis are common.

By far the richest fauna is the top one which occurs between about 540 and $610 \mathrm{~m}$ above the base of the Singing Creek Formation. The following fossils are present:

Trilobita: Micragnostus, Pseudagnostus idalis denisonensis, P. sp., Denagnostus corbetti, Asphelaspis cantori, a member of the Leiostegiacea, Proceratopyge gordonensis, $P$. sp., and trilobite tracks.

Hyolithida: Hyolithid, gen. et sp. indet.

Brachiopoda: Obolus (?) sp.; Obolidae, gen. et sp. inder. 1; Obolidae, gen. et sp. indet. 2; Acrotretidae, gen. et sp. indet. 2 and Billingsella sp. 2.

Jago (1987) suggested that the faunas of the Singing Creek Formation are of early Late Cambrian age and fall within the range of the top three Idamean Zones, i.e. Proceratopyge cryptica, Erixanium sentum and Stigmatoa diloma Zones. All specimens described here are preserved as internal and external moulds in weathered siltstone or very fine sandstone. In order to prepare them for description, silicone rubber casts were prepared. These rubber casts were then photographed after being whitened with magnesium oxide Unfortunately the brachiopods, particularly the inarticulate brachiopods, are generally poorly preserved.

The terminology used for brachiopods is after Williams \& Rowell (1965a,b). All specimens are housed in the collection of the Geology Department, University of Tasmania. The catalogue numbers refer to this collection.

\section{SYSTEMATIC DESCRIPTIONS}

Phylum BRACHIOPODA Dumeril 1806
Class INARTICULATA Huxley 1896
Order LINGULIDA Waagen 1885
Family OBOLIDAE King 1846
Subfamily LINGULELLINAE Schuchert
1893
Genus LINGULELLA Salter 1866

Type species: Lingula davisii M'Coy 1851: 405.

$$
\text { Lingulella (?) sp. (pl. 1A-C) }
$$

Remarks: The available material comprises three internal and one external mould, all of which appear to belong in the one species. They belong in Lingulella or a related genus, as is indicated by their outline and ornamentation. They are too poorly preserved to warrant description.

PLATE 1

(A-C) Lingulella (?) sp.1: (A) UT89445, internal mould of pedicle valve, $\times 7$. (B) UT89515, internal mould of pedicle valve, $\times 6$. (C) UT89449, external mould of pedicle valve, $\times 5$

(D-H) Obolus (?) sp.4: (D) UT89430, internal mould of brachial valve, $\times 6$. (E) UT88427, internal mould of pedicle valve, $\times 4.5$. (F,G) UT89431, counterparts showing both valves; $(F) \times 5,(G) \times 6$. (H) UT88433, internal mould of (?)pedicle valve, $\times 6$.

(I) Acrotretidae, gen. et $s p$. indet. 1, UT89515, internal mould of pedicle valve, $\times 12$.

$(J-L)$ Obolidae, gen. et sp. indet. $1:(J)$ UT88432, internal mould, $\times 3.5 ;(K)$ UT88423, internal mould, $\times 6$. (L) UT88435, internal mould, $\times 5.5$.

(M) Obolidae, gen. et sp. indet. 2. UT88429, internal mould, $\times 3.5$

$(N, O)$ Acrotretidae, gen. et sp. indet. 2: (N) UT8843I, external mould of brachial valve, $\times 6$.

(O) UT88410, internal mould of brachial valve, $\times 9$. 

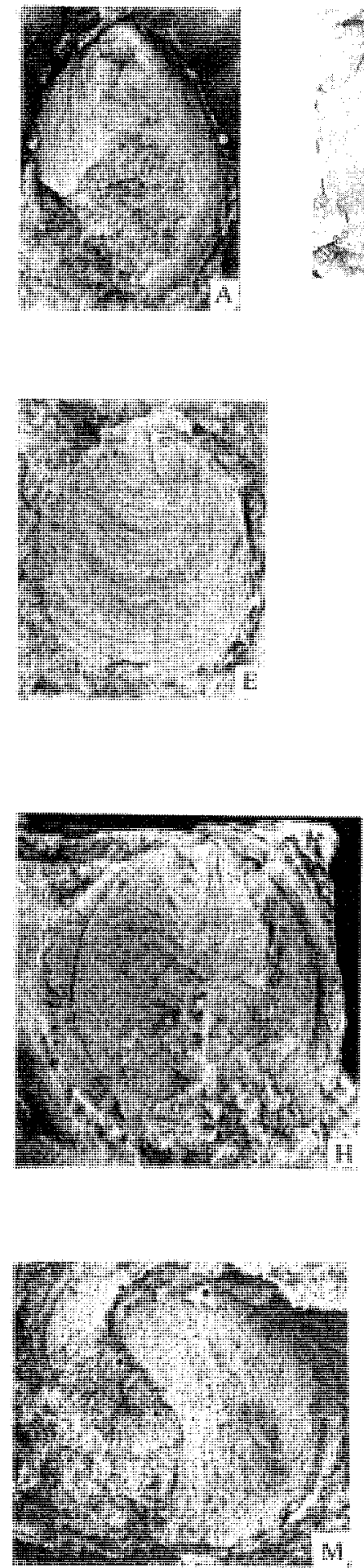
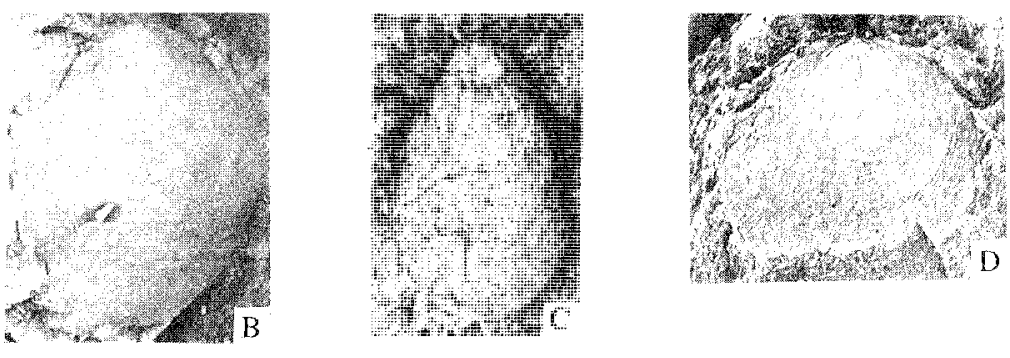

W. W w r w

$4+4$
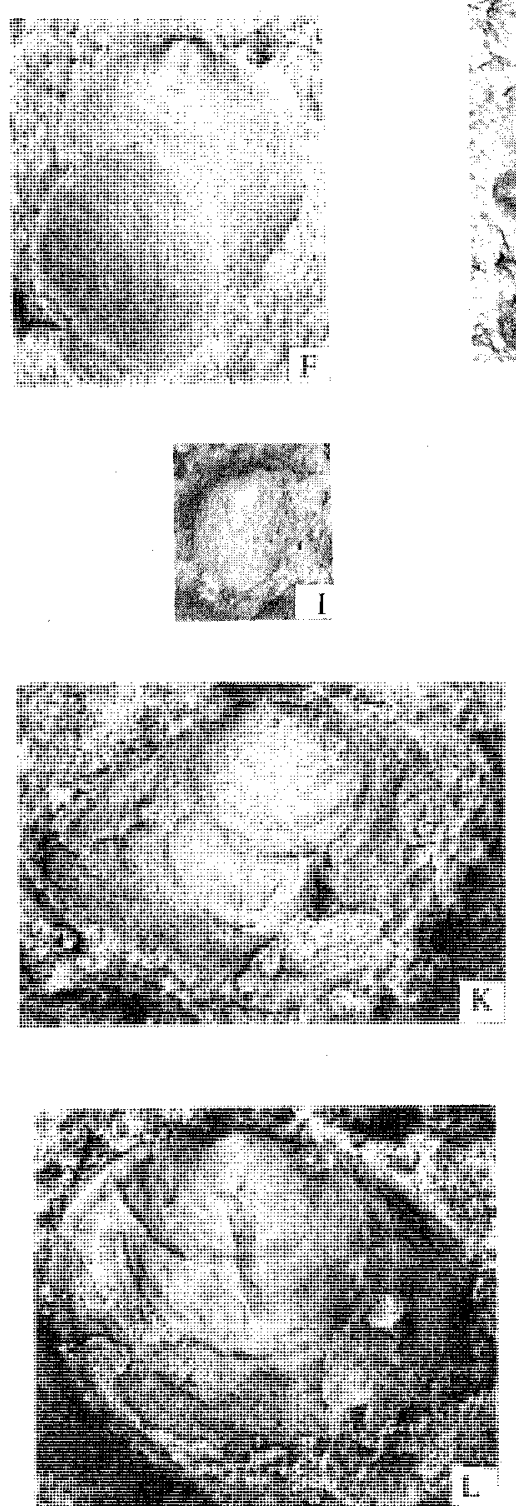
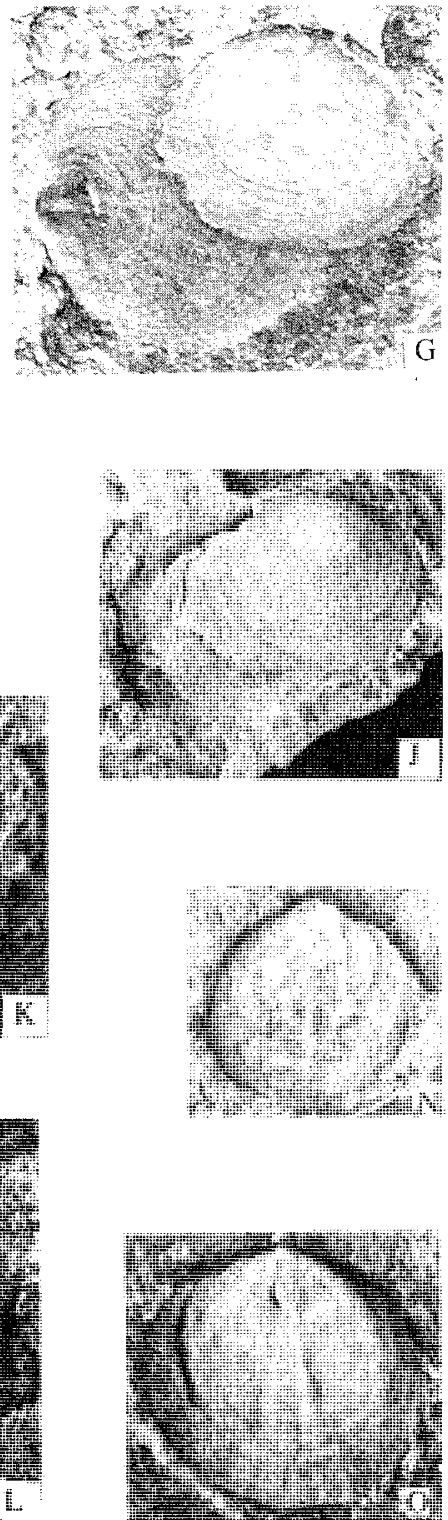


\section{S ubfamily OBOLINAE King 1846 Genus OBOLUS Eichwald 1829}

Type species: Obolus apollinis Eichwald 1829: 274 (pl. 4, figs 5A-B).

$$
\text { Obolus (?) sp. (pl. 1D-H) }
$$

Material: Three pedicle and two brachial valves preserved as either internal or external moulds. Remarks: If it is assumed that the two valves which occur together on specimen UT89431 (pl. 1F,G) originally belonged to the same individual, then the pedicle valve is slightly larger than the brachial valve. Both valves are gently convex and have a circular to oval outline; both show fine concentric growth lamellae. The general appearance of the available specimens suggests that they belong in Obulus, to which genus they are tentatively assigned.

Obolidae, gen. et sp. indet. no.1 (pl. 1J-L)

Remarks: Internal moulds of three valves of a probable member of the Obolidae are figured. The details are such that it can not be determined whether they are brachial or pedicle valves.

Obolidae, gen. et sp. indet. no.2 (pl. 1M)

Remarks: One partially preserved valve exhibits closely spaced growth lamellae. There are minute spines on the surface of the valve, particularly in the posterior region. Discontinuous vascular markings are visible, particularly in the anterior part of the valve.

Order ACROTRETIDA Kuhn 1949 Suborder ACROTRETIDINA Kuhn 1949 Superfamily ACROTRETACEA Schuchert 1893

Family ACROTRETIDAE Schuchert 1893 Acrotretid, gen. et sp. indet.1 (pl. 1I)

Remarks: One poorly preserved small conical pedicle valve of an acrotretid is present. It is too poorly preserved to allow generic identification.

Acrotretid, gen. et sp. indet. no.2 (pl. 1N,O)

Material: Four poorly preserved brachial valves are available.

Remarks: These valves which have an almost semicircular outline show faintly developed growth lamellae. Their outline is similar to that of Quadrisonia minor of Rowell \& Henderson (1978) from the Upper Cambrian of North America, but until better preserved material is available this material must be left in open nomenclature.

\section{Class ARTICULATA Huxley 1869 Order ORTHIDA Schuchert and Cooper 1932 \\ Suborder ORTHIDINA Schuchert and Cooper 1932 \\ Superfamily BILLINGSELLACEA Schuchert 1893}

Family BILLINGSELLIDAE Schuchert $\mathbf{1} 893$ Genus BILLINGSELLA Hall and Clarke 1893

Type species: Orthis pepina Hall 1863: 134, pl. 6, figs 23-27.

Comment: As noted by Mackinnon in Shergold $e t$ al. (1976) Billingsella is a cosmopolitan genus of Middle Cambrian to Early Ordovician age. Although it has been recorded from Late Cambrian sequences in Tasmania by various authors (e.g. Banks 1962, Corbett 1975, Jago 1979), the specimens dealt with below are the first to be described and figured from Tasmania.

\section{Billingsella sp.1 (pl. 2A-J)}

Material: All specimens are disarticulated. Six brachial and twelve pedicle valves are available.

Description: Gently convex pedicle valve with subtrapeziform outline, widest at hinge line; apsacline ventral interarea about four times as wide as long; posterolateral margins of ventral interarea slightly concave; gently convex pseudodeltidium covers apical half of delthyrium; cardinal extremities angular, acute to right-angled; low median fold; slightly concave posterolateral slopes; external ornamentation parvicostellate with costellae most prominent on fold margins; variably developed concentric growth lines; details of teeth and musculature not clear on available material.

Almost flat, subrectangular brachial valve, widest at hinge line; cardinal extremities almost rightangled; shallow median sulcus; dorsal interarea details not visible on available material; external ornamentation parvicostellate with costellae most prominent in, and on the margins of the sulcus; variably developed concentric growth lines; in brachial valve interior are widely divergent socket ridges; notothyrial platform bears narrow ridge-like cardinal process. 

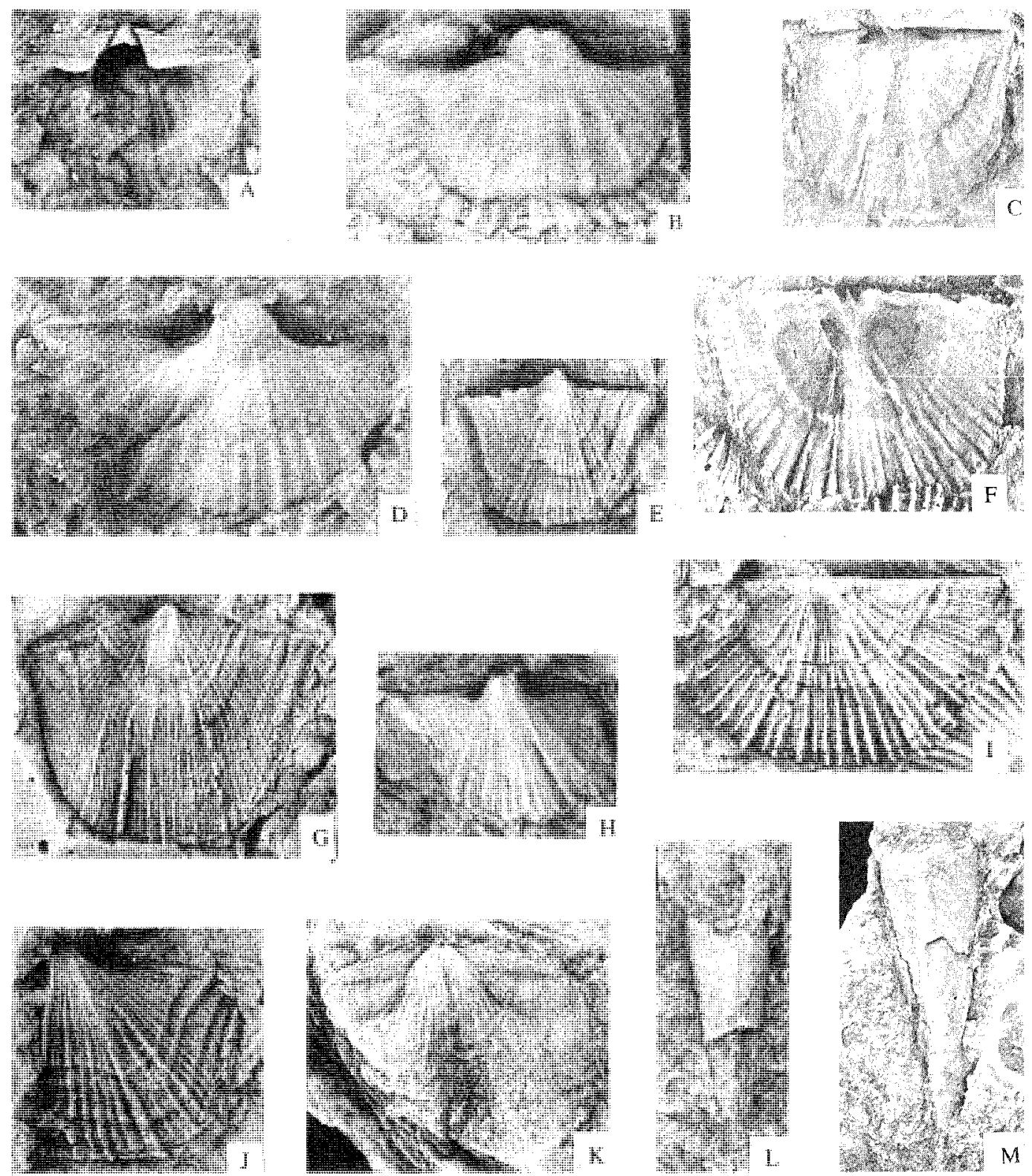

PLATE 2

(A-J) Billingsella sp.1: (A) UT89514, internal mould of pedicle valve, $\times 4$. (B) UT89515, internal mould of pedicle valve, $\times 5$. (C) UT89514, internal mould of brachial valve, $\times 6$. (D) UT89513, internal mould of pedicle valve, $\times 5$. (E) UT89514, external mould of pedicle valve, $\times 3 . \quad(F)$ UT89516, internal mould of brachial valve, $\times 2 .(G)$ UT89514, external mould of pedicle valve, $\times 3$. (H) UT89515, internal mould of pedicle valve, $\times 4$. (1) UT89516, external mould of brachial valve, $\times 2$. (J) UT89515, external mould of brachial valve, $\times 6$.

(K) Billingsella sp.2, UT88508, internal mould of pedicle valve, $\times 3$.

(L-M) Hyolithid, gen. et sp. indet.: (L) UT88390, internal mould, dorsal view, $\times 3$. (M) UT88393, internal mould, ventral view, $\times 4$. 
Discussion: As noted by Mackinnon in Shergold et al. (1976) there is little published data on southern hemisphere species of Billingsella. Billingsella sp. 1 (described above) differs from both Billingsella sp. indet. (described by Mackinnon in Shergold et al. (1976) from northern Victoria Land, Antarctica) and Billingsella sp. (described by Percival in Powell et al. (1982) from western New South Wales) in having a lower ventral interarea. The external ornamentation on both valves of the Tasmanian specimens is stronger than those on either the New South Wales or Antarctic species noted above. No species of Billingsella other than those mentioned above have been described from Australia or Antarctica; all three are of Idamean age.

\section{Billingsella sp.2 (plate $2 \mathrm{~K}$ )}

Remarks: Several generally poorly preserved disarticulated valves are available. The only reasonably well preserved specimen, an internal mould of a pedicle valve, is figured. This pedicle valve differs from those described as Billingsella sp. 1 in that it is widest somewhat to the anterior of the hinge line, whereas Billingsella sp.I is widest at the hinge line. This, plus the fact that it comes from a higher stratigraphic horizon than Billingsella sp.1, suggests that it belongs in a different species of Billingsella.

\section{Phylum MOLLUSCA}

Class HYOLITHA Marek 1963

Order HYOLITHIDA Matthew 1899

Hyolithid, gen. et sp. indet. (pl. 2L,M)

Remarks: Five poorly preserved hyolithid specimens are available. The dorsal side is gently convex; the ventral side bears a prominent longitudinal rib, the divergence angle is $15-20^{\circ}$. The available material does not allow assignment of the specimens to a particular genus or species.

\section{ACKNOWLEDGEMENTS}

The fossils were collected by Dr K.D. Corbett (Geological Survey of Tasmania); the cataloguing and transport of the fossils from Hobart to Adelaide were arranged by Dr M.R. Banks and Ms P.L. Green (University of Tasmania). I wish to thank Drs J.H. Shergold and J. Laurie (Bureau of Mineral Resources, Canberra) and Dr R.A. Henderson (James Cook University, Townsville) for valuable advice. This work was supported by a grant from the Australian Research Council.

\section{REFERENCES}

BANKS, M.R., 1962: The Cambrian System. In Spry, A.H. \& Banks, M.R. (Eds): THE GEOLOGY OF TASMANIA. J. Geol. Soc. Aust. 9: 127-145.

CorbetT, K.D., 1972: Features of thick-bedded sandstones in a proximal flysch sequence, Upper Cambrian, south-west Tasmania. Sedimentology 19: 99-114.

Corbert, K.D., 1973: Open-cast slump sheets and their relationship to sandstone beds in an Upper Cambrian flysch sequence, Tasmania. J. Sedim. Petrol. 43: $147-159$.

Corbett, K.D., 1975: The Late Cambrian to Early Ordovician sequence on the Denison Range, southwest Tasmania. Pap. Proc. R. Soc, Tasm. 109: 111-120.

Erchwald, E., 1829: Zoologia specialis, quam expositis animalibas tum vivis, tum fossilibus potissium Rossiae in universum et Poloniae in specie etc. Vol.1, 314 pp., 5 pls (Vilnae).

Hall, J., 1863: Preliminary notice of the fauna of the Potsdam Sandstone, with remarks on the previously known species of fossils and decriptions of some new ones from the sandstone of the upper Mississippi valley. 16th Ann. Rep. N.Y. Cab. Nat. Hist., App.D, Contributions to Paleontology: 119-184, pls Va-XI.

JAGO, J.B., 1979: Tasmanian Cambrian biostratigraphy a preliminary report. $J$. Geol. Soc. Aust. 26: 223-230.

JAGo, J.B., 1987: Idamean (Late Cambrian) trilobites from the Denison Range, south-west Tasmania. Palaeontology 30: 207-231.

M'Coy, F., 1851: On some new Cambro-Silurian fossils. Ann. Mag. Nat. Hist. 20: 387-409.

Powell, C.M., Neef, G., Crane, D., Jell, P.A. \& Percival, I.G., 1982: Significance of Late Cambrian (Idamean) fossils in the Cupala Creek Formation, northwestern New South Wales. Proc. Linn. Soc. N.S.W. 106: 127-150, figs 1-12.

Rowell, A.J. \& Henderson, R.A., 1978: New genera of acrotretids from the Cambrian of Australia and the United States. Univ. Kansas, Paleont. Contrib., Paper 93: 1-12, pls 1-2.

Shergold, J.H., Cooper, R.A., MacKinnon, D.I. \& Yochelson, E.L., 1976: Late Cambrian Brachiopoda, Mollusca, and Trilobita from northern Victoria Land, Antarctica. Palaeontology 19: 247-291, pls 38-42.

Williams, A. \& Rowell, A.J., 1965a: Morphology. In Moore R.C. (Ed.): TREATISE ON INVERTEBRATE PALEONTOLOGY, Part H: H57-H138, figs 59-138. Geological Society of America \& University of Kansas Press.

Williams, A. \& Rowell, A.J., 1965b: Morphological terms applied to brachiopods. In Moore R.C. (Ed.): TREATISE ON INVERTEBRATE PALEONTOLOGY, Part H: H139-H155. Geological Society of America \& University of Kansas Press.

(accepted 20 February 1989) 